\title{
Sérgio Sant'Anna - O livro de Praga: narrativas de amor e arte
}

São Paulo: Companhia das Letras, 2011.

\author{
Igor Ximenes Graciano*
}

O livro mais recente de Sérgio Sant'Anna foi escrito sob encomenda. E isso não é uma informação acessória sobre a obra, curiosidade acerca do que é anterior e exterior à sua composição ou mesmo sua leitura. O adendo "sob encomenda" mais o fato dessa encomenda fazer parte de uma série - uma coleção organizada por uma grande casa editorial - constitui algo central na compreensão (fruição) desse conjunto de narrativas assinadas pelo escritor carioca. Pode-se mesmo falar que é um dos temas subterrâneos do livro.

E do que trata esse O livro de Praga? De um escritor, Antônio Fernandes, que visita a capital da República Tcheca como participante de "um projeto privado que envia escritores brasileiros a várias cidades do mundo (...) para escrever histórias de amor" (p. 14). Enfim, a velha confusão almejada entre o dentro e o fora da representação literária, pois sabemos de antemão que $O$ livro de Praga é a mais recente publicação da série "Amores expressos", projeto não por acaso semelhante ao descrito pelo protagonista das narrativas de Sant'Anna.

E assim seguimos as andanças de Antônio Fernandes pelas ruas de Praga à procura de seu texto, suas "histórias de amor". Ao leitor mais desconfiado é quase inevitável a sensação de embuste diante da saída conveniente do escritor (Sant'Anna? Fernandes?) a fim de honrar sua parte no contrato com a editora. Afinal, se é para escrever, por que não começar pelo óbvio? E o óbvio é um escritor-turista em uma bela cidade da Europa central pedindo dinheiro ao seu "chefe", o editor, para pagar uma audição particular no Museu Kampa, mote da primeira das sete narrativas, "A pianista". Acertados os trâmites financeiros e as condições da audição, quando Fernandes sobe por uma "escada em caracol" acompanhado da figura hostil e corcunda de Jean Louis - espécie de secretário da pianista, certamente apaixonado por ela -, rapidamente percebe-se que entramos em território de cores menos corriqueiras. Do banal aflora o estranho, o inesperado: o excedente que é a própria ficção, instância em que a cidade se revela para o (pelo) indivíduo criador.

O insólito concerto da senhorita Béatrice Kromnstadt se dá em uma torre do museu, ao final da escadaria, em uma sala acusticamente vedada (espaço

\footnotetext{
* Doutorando em Literatura Comparada na Universidade Federal Fluminense (UFF)

E-mail: ixgraciano@gmail.com
} 
por demais simbólico: distante e secreto). A composição executada por Béatrice, de um certo Voradeck, sobre quem ele havia pesquisado algo na internet momentos antes, assim como sobre a pianista, "era uma busca do impossível, de uma música que tenderia para o infinito" (p. 25). Enfim, o escritor-turista encontra seu motivo, a fresta por onde se meter e tirar sua composição em palavras: "É evidente que só depois dessa audição tornei-me capaz desta escrita" (p. 25). A subida de Fernandes na torre é como a queda de Alice na toca do coelho branco, dali para diante nada será como normalmente foi: "ao sair para o pátio, e depois para o parque de Kampa, tive a sensação de despertar de um sonho, e a própria realidade me pareceu irreal" (p. 45).

Uma vez deflagrada, essa realidade irreal se espalha pelas narrativas seguintes, como um longo e acidentado sonho erótico em torno de uma mesma figura de mulher, a qual se repete nas várias que Fernandes encontra em sua estadia em Praga: jovem, branca, muito magra, aparentemente frágil. Com elas o escritor "vive" suas histórias de amor, cada uma como negação do que se espera de uma narrativa do gênero. Em determinado momento de O livro, o narrador esclarece: "O meu eu, seja lá em que medida ele fora integrado antes, se partira, se perdera, e não era necessariamente por causa de minha nova aparência, e sim porque, depois de experiências tão marcantes, de amores até bizarros, eu jamais poderia voltar a ser o mesmo" (p. 79).

Partido, o eu é tão volátil quanto as imagens e seres que narra, dificultando assim a recepção da obra sob uma perspectiva realista, onde o que lemos é presumivelmente fruto de uma vivência turística, com encontros fortuitos e aventuras inusitadas. A experiência de Fernandes com Praga e seus viventes, até mesmo seus fantasmas, não resulta de uma lembrança que nos é descrita, mas é já a escrita, seu gesto em si como produção da cidade, dos enlaces sexuais, do eu que se constitui no momento que conta. Na narrativa "O texto tatuado", ele busca conhecer um manuscrito talvez inédito de Kafka tatuado no corpo de Jana, que cobra para deixar-se ler completamente nua. Extremamente excitado pela exposição, Fernandes procura tocar seu corpo, mas ela o detém: "aqui é a linguagem que comanda tudo, só a linguagem" (p. 117).

O entrecho-chave de O livro de Praga se dá em "A boneca", quando o narrador assiste ao espetáculo Aspects of Alice, do Ta Fantastika Black Light Theatre. Trata-se de uma encenação de luz e sombra sobre a personagem de Lewis Carrol onde, em determinado momento, Alice se desprende de sua sombra, quando esta deixa de persegui-la, criando vida própria. Numa inversão de papéis, é Alice quem persegue sua sobra, chamando-a, mesmo nomeando-a: Gertrude. Ao final, “a menina-sombra quedou-se imóvel, vencida, e Alice atravessou um espelho criado pela luz - numa referência clara a Através do espelho e o que Alice encontrou lá - e as duas, a menina e sua sombra, lançaram-se nos braços uma da outra" (p. 81-2). 
Resenhas

Nada mais significativo do que essa imagem, que se abre como alegoria para a composição desse e de outros livros de Sant'Anna. O autor e sua sombra ficcional - no caso Antônio Fernandes - começam unidos aos olhos do leitor, pela óbvia semelhança dos tipos e da situação, até que com o correr da pena não mais se possa imputar ao autor qualquer responsabilidade sobre os atos da sombra, que se desprende e vale por si, como personagem autônomo, jamais reflexo. Tendo em vista, porém, o desfecho da imagem do espetáculo, em que corpo e sombra se abraçam, onde estaria, nas narrativas de $O$ livro de Praga, esse ponto de encontro, esse retorno ao mesmo? Não sendo possível aqui (se é que seria em outro lugar) fechar a questão, resta o recurso à conjectura. E na conjectura eu diria que o encontro está no que reluz em todo exercício de autorrepresentação ficcional: aquilo que se mostra pelo desvio, ou, nos termos da teoria da ficção, o texto como realização de um imaginário. Nisso, no que há de palpável e mesmo de irremediável na escrita, Antônio Fernandes abraça Sérgio Sant'Anna, sem que um deixe de ser sombra e o outro corpo.

A literatura resulta, portanto, como pulsão de um imaginário. Um certo imaginário localizado, certamente, em que o corpo do homem se projeta em fantasias, terreno propício ao clichê da "falta de limites" - típico quando se trata da imaginação enquanto produtora. Literatura, enfim, (e poderíamos dizer "ficção") como extensão e caminho à realização dos desejos, ainda que tal realização seja sempre insuficiente: "então eu deveria permanecer com o desejo aceso, o desejo infindável de quem não se sacia, possuindo Jana apenas com a visão de seu corpo com suas letras, palavras e fantasias" (p. 120). Por esse desejo como sopro à verve criativa, Sant'Anna nunca esteve tão próximo de seu amigo e colega de ofício, João Gilberto Noll.

E assim se perfaz a participação de Sant'Anna na controversa coleção "Amores expressos", pela saga-texto de Antônio Fernandes, escritor-turista. Se o contrato foi bem cumprido ou não, cabe ao leitor julgar. Nessa empreitada "sob encomenda", entretanto, com altos e baixos, erros e acertos, não se pode negar o privilégio do risco a essas "narrativas de amor e arte". Fechando-se O livro de Praga, reverbera em algum lugar da lembrança (a leitura como lembrança), a sentença do narrador a respeito da performance da pianista sobre a peça de Voradeck, com direção de Svoboda, invisível mas onipresente em toda a cena:

Foram eles três, Voradeck, Béatrice, Svoboda, que, para melhor ou para pior, me abriram esses caminhos, que podem me levar a sofrer críticas devastadoras e impiedosas, como eles mesmos sofreram, pois houve - li na web - quem chamasse Voradeck e Svoboda de sonorizadores e encenadores de uma parafernália circense, em que Béatrice era a contorcionista do piano, e devo reconhecer que ela, ou eles todos, trafegava na corda bamba sem rede por baixo. (p. 25) 